\title{
The Relationships between Socio-demographic Variables, Travel Motivations and Subsequent Choice of Vacation
}

\author{
Jan Moller Jensen \\ Department of Marketing and Management, University of Southern Denmark, Denmark
}

Copyright (C) 2015 by authors, all rights reserved. Authors agree that this article remains permanently open access under the terms of the Creative Commons Attribution License 4.0 International License

\begin{abstract}
This study explores the relationship between socio-demographic variables and travel motivation and further investigates how travel motivations influence the travelers' choice of vacation. The data were obtained using an internet-based questionnaire administered to a random sample of 256 respondents. Using factor analyses, six motivational factors, thematically similar to other studies on travel motivation, were identified. In contrast to previous research on travel motivations among travelers from other countries, this study identified 'social relationship with family/friends' as the most important motivational factor for Danish travelers. The results show that travel motivations differ across various socio-demographic variables and that travel motivations are related to the travelers' choice of vacation. The article closes with a discussion of the implications of these findings and suggestions for future research.
\end{abstract}

Keywords Socio-demographic Characteristics, Travel Motivation, Travel Type, Destination

\section{Introduction}

While motivation is only one of many variables shaping tourism behavior, it is commonly acknowledged by tourism professionals and academics alike that it is a critical variable because it is the driving force behind all behavior [1]. From this perspective, it is no wonder that a plethora of researchers have sought to explore travel motivations, for example [1-8]. Several travel motives have been detected and researchers argue that by understanding these motives, tourism marketers can develop more effective marketing strategies [9]. Yet, as pointed out by Kozak [7] there is a need for more empirical research investigating how travel motives differ among various travel segments and how travel motives are related to the travelers' choice of vacation. To move the research forward, the present article sets out to examine the relationships between socio-demographic variables, travel motivations, and subsequent choice of vacation. More specifically the article aims at identifying and measuring travel motivations among Danish travelers, and then to answer the following research questions:

Q1: What are the relationships between travel motivation and socio-demographic characteristics?

Q2: What are the relationships between travel motivations and the travelers' choice of vacation?

To that end, the article begins by briefly summarising some of the main approaches to travel motivations and their relationship to socio-demographic variables and travellers choice of vacation. Next, an empirical study, aimed at measuring travel motivations among Danish travellers and providing answers to the above mentioned research questions, is presented. Results are reported and their implications for theory and practice are discussed at the end of the article.

\section{Theoretical Background}

\subsection{Travel Motivation}

Travel motivations are the reasons for travel and are also believed to explain why tourists prefer a specific travel type and make the decision to destination over another [2]. A useful and generally accepted theory used to examine travel motivation is the theory of push- and pull factors [2,3]. Push factors have been thought useful for explaining the desire to travel, while pull factors help explain preferences for travel type or the choice of destination [2]. Several researchers have attempted to identify push factors driving individuals to travel $[6,8,10-13]$. Among the most common push factors found in these studies were 'escape from routine everyday life', 'relaxation', 'exploration', 'social interaction', 'relationship enhancement' and 'prestige'.

\subsection{The Relationship between Travel Motivation and Socio-demographic Characteristics}

Several studies have attempted to examine the 
relationship between travel motivation and various socio-demographic variables such as gender, age, educational level, and income. For example, Gitelson and Kerstetter [4] evidenced that females rated relaxation, socializing and exploration as more important than the male respondents. They also found that age was negatively related to the importance of relaxation, excitement, socializing and exploration. Zimmer et al. [14] showed that age, income and education were important predictors of a person's desire to travel. Their study also proved that travelers with higher educational background and more disposable income were more likely to travel farther from home. Sangpikul [15] in a study of senior travelers evidenced that educational level was positively related to travelers' intensions to travel. Their findings also showed that relaxation, seeking knowledge and novelty were more important push motives among travelers with a higher educational level.

\subsection{The Relationship between Travel Motivation and Choice of Vacation}

Although the tourism literature commonly describes push motivations as those factors explaining the traveler's desire to travel while pull factors help explain the choice of destination or preferences for travel type [2], it seems plausible to expect that different motivational factors push the traveler towards different destinations and travel types. As an example, a traveler driven by the push motive of exploration may be more likely to travel to an unknown far-away destination than a traveler driven by the motive of relaxation. Likewise, a traveler pushed by the motive of relaxation is more likely to become a traditional charter sun and beach tourist than a traveler seeking exploration. Although several researchers have attempted to relate tourist motivations to destination choice (e.g., [16]), studies investigating the relationship between tourist motivation and travel types are rare.

\section{Research Design}

\subsection{Measurement Instrument}

A web-based questionnaire was designed to collect information about the travel behavior of Danish travelers. In the first section, the respondents were asked to provide information on various socio-demographic variables including gender, age, education and income. In the next section, the respondents were asked to think back on their entire vacation-related travel (excluding business travel) over the last five years. Respondents were asked to indicate their choice of travel type, and to what extent their choices of travel destinations were domestic, within Europe or outside Europe. As for the construct of travel motives, a variety of statements were selected from the review of past literature (e.g., [8,10-13]). 14 of the selected statements were aimed at measuring five of the most frequently mentioned push motivational factors: escape, relaxation, social relationship with family/friends, exploration and prestige/impression. An additional four items were included in order to measure the travelers' appraisal of natural resources and famous sites/heritages. The respondents were asked to rate, on a scale ranging from 1 (= extremely unimportant) to 5 (= extremely important) the importance the 18 push motivational statements in relation to their desire to go on a vacation.

\subsection{Data Collection}

Students in a marketing research class contacted 701 households, randomly drawn from the telephone directory of a major city (Odense) in Denmark. The students were closely supervised by the author about the data collection procedure. In order to qualify for the study, households were required to have access to the Internet, and at least one person in the household must travel at least once every second year. From the around 600 qualified households, a total of 256 respondents ( $42.7 \%$ response rate), 102 males and 154 females aged from 17 to 70 years old, returned useable questionnaires.

\section{Data Analysis and Results}

\subsection{Principal Component Analysis}

Principal component analysis using the varimax rotation was first performed on the 18 push motivational items in order to explore the underlying push factors. The Kaiser-Meier-Olkin measure of sampling adequacy (0.73) and Bartlett's test of sphericity $(\mathrm{p}=0.000)$ proved that the data was appropriate to conduct a factor analysis. 
Table 1. Factor analysis with varimax rotation for travel motivations of Danish travelers

\begin{tabular}{|c|c|c|c|c|c|}
\hline Motivational factor and items ${ }^{\mathrm{a}}$ & $\begin{array}{l}\text { Factor } \\
\text { loading }\end{array}$ & Communalities & $\mathrm{EV}^{\mathrm{b}}$ & $\begin{array}{c}\text { Pct of } \\
\text { variance }\end{array}$ & $\begin{array}{l}\text { Factor } \\
\text { Means }^{\mathrm{c}}\end{array}$ \\
\hline Factor $1-$ Exploration $(\text { alpha }=0.83)^{\mathrm{d}}$ & & & 2.78 & $15.4 \%$ & $3.42(0.88)$ \\
\hline Expand my horizons & .810 & .706 & & & \\
\hline Experiencing other cultures & .797 & .737 & & & \\
\hline Experiencing new or different lifestyles & .792 & 699 & & & \\
\hline To increase knowledge about other countries & .672 & .637 & & & \\
\hline Factor $2-$ Escape/Relax (alpha $=0.83)$ & & & 2.67 & $14.9 \%$ & $3.80(0.92)$ \\
\hline Escape from work responsibilities/stress & .852 & .752 & & & \\
\hline To seek release from work pressure & .828 & .713 & & & \\
\hline Get away from everyday life/routine & .820 & .708 & & & \\
\hline To rest and relax & .704 & .588 & & & \\
\hline Factor 3 -Social relationship with family/friends $($ alpha $=.91)$ & & & 2.62 & $14.6 \%$ & $4.26(0.93)$ \\
\hline Have experiences together with family/friends & .916 & .845 & & & \\
\hline Spend time with family/friends & .913 & .851 & & & \\
\hline Socialize with family/friends & .908 & .864 & & & \\
\hline Factor 4 - Prestige/impression (alpha $=0.71)$ & & & 1.91 & $10.7 \%$ & $2.07(0.85)$ \\
\hline Visit a place in order to impress friends & .839 & .708 & & & \\
\hline Experience something to tell others about & .755 & .631 & & & \\
\hline Travelling to a destination that friends and relatives have never been to & .739 & .619 & & & \\
\hline Factor 5-Appreciating natural resources $($ alpha $=0.78)$ & & & 1.67 & $9.3 \%$ & $3.66(0.97)$ \\
\hline Experience sites of natural beauty & .850 & .811 & & & \\
\hline Experience nature in other countries & .828 & .817 & & & \\
\hline Factor 6 - Appreciating famous sites/heritages (alpha $=0.73$ ) & & & 1.59 & $8.8 \%$ & $3.05(0.81)$ \\
\hline Visit famous sites and heritages & .863 & .829 & & & \\
\hline Visit cultural/historical sites & .712 & .745 & & & \\
\hline
\end{tabular}

Note: ${ }^{\text {a }}$ Eighteen vacation motives captured in six factors.

${ }^{\mathrm{b}}$ Eigenvalue

${ }^{\mathrm{c}}$ Mean scale: 5 = extremely important, 1 = extremely unimportant; standard deviations in parentheses

${ }^{\mathrm{d}}$ Chronbach's Alpha

Table 1 shows the six push motivational factors with eigenvalues greater than 1.0. Most variables loaded heavily on one factor (range from 0.672 to 0.916 ) and not heavily on others, thereby indicating minimal overlap among the six dimensions [17]. The communality of each variable ranged from 0.588 to 0.864 , indicating that the variance in each of the 18 push items was fairly captured by the six factors. The six factors account for 73.7 percent of the variance in the data, thereby illustrating that most of the original variance is captured in the six-factor solution. Internal consistency between items representing each factor was assessed using the Cronbach's alpha coefficient. The resulting coefficients were all above the commonly-accepted minimum limit of 0.70 [17]. The six factors were labeled as: 'exploration', 'escape/relaxation', 'social relationship with family/friends', 'prestige/impression', 'appreciating natural resources' and 'appreciating famous sites/heritages'. To assess the importance attributed to each factor, a 'summated scale' was employed by calculating the average score of the variables loaded on each factor.

Factor mean scores and corresponding standard deviations are displayed in the last column in Table 1. The results indicate that the Danish travelers perceive 'social

relationship with family/friends' (Factor 3) as the most important travel motive, followed by, in descending order of importance, 'escape/relaxation' (Factor 2), 'appreciating natural resources' (Factor 5), 'exploration' (Factor 1), 'appreciating famous sites/heritages' (Factor 6) and 'prestige/impression' (Factor 4). All factors other than the 'prestige/impression' motive scored above 3.0, indicating that these push motivations were deemed fairly important to the Danish travelers.

\subsection{The Relationship between Travel Motivation and Socio-demographic Characteristics}

Having assessed the importance of the six push motivational factors, the next step is to clarify whether these motivational factors differ across various demographic groups. To achieve this aim, a series of t-test and one-way ANOVA tests, coupled with post hoc multiple comparisons, were conducted to test differences with respect to gender, age, education and income. The mean scores for each sub-group along with the results of the univariate test are shown in Table 2. 
Table 2. T-tests of mean differences of motivational factors by travelers' choice of vacation type

\begin{tabular}{|c|c|c|c|c|c|c|c|}
\hline $\begin{array}{l}\text { Socio-demographic } \\
\text { variables }\end{array}$ & $\mathrm{N}$ & Exploration & $\begin{array}{l}\text { Escape/ } \\
\text { relaxation }\end{array}$ & $\begin{array}{c}\text { Social relationship } \\
\text { with family/ } \\
\text { friends }\end{array}$ & $\begin{array}{l}\text { Prestige/ } \\
\text { impression }\end{array}$ & $\begin{array}{l}\text { Appreciating } \\
\text { natural } \\
\text { resources }\end{array}$ & $\begin{array}{l}\text { Appreciating } \\
\text { famous } \\
\text { sites/heritages }\end{array}$ \\
\hline Gender & & $\mathrm{t}=-4.954^{* *}$ & $\mathrm{t}=-2.302^{*}$ & $\mathrm{t}=-3.435^{* *}$ & $\mathrm{t}=2.234^{*}$ & $t=-1.360$ & $\mathrm{t}=-2.250^{*}$ \\
\hline Male & 102 & 3.08 & 3.63 & 4.01 & 2.22 & 3.56 & 3.27 \\
\hline Female & 154 & 3.64 & 3.90 & 4.43 & 1.98 & 3.73 & 3.55 \\
\hline Age & & $F=1.785$ & $F=1.406$ & $\mathrm{~F}=9.154^{* *}$ & $\mathrm{~F}=5.109^{* *}$ & $\mathrm{~F}=3.085^{*}$ & $\mathrm{~F}=0.941$ \\
\hline $18-24$ & 47 & 3.39 & 3.70 & $4.53^{\mathrm{b}}$ & $2.38^{\mathrm{a}}$ & $3.32^{\mathrm{a}}$ & 3.48 \\
\hline $25-34$ & 57 & 3.34 & 3.88 & $4.17^{\mathrm{b}}$ & $2.26^{\mathrm{a}}$ & 3.59 & 3.32 \\
\hline $35-44$ & 46 & 3.26 & 3.92 & $4.30^{\mathrm{b}}$ & 2.04 & 3.59 & 3.29 \\
\hline $45-54$ & 66 & 3.65 & 3.86 & $4.54^{\mathrm{b}}$ & 1.96 & $3.86^{\mathrm{b}}$ & 3.51 \\
\hline $55-64$ & 40 & 3.36 & 3.53 & $3.57^{\mathrm{a}}$ & $1.67^{\mathrm{b}}$ & $3.91^{\mathrm{b}}$ & 3.61 \\
\hline Education & & $\mathrm{F}=0.520$ & $\mathrm{~F}=4.865^{* *}$ & $\mathrm{~F}=0.915$ & $\mathrm{~F}=8.756^{* *}$ & $\mathrm{~F}=2.817^{*}$ & $\mathrm{~F}=2.134$ \\
\hline Primary school & 78 & 3.33 & $3.77^{\mathrm{a}}$ & 4.37 & $2.41^{\mathrm{a}}$ & $3.46^{\mathrm{a}}$ & 3.30 \\
\hline High school/college & 42 & 3.49 & $4.23^{\mathrm{b}}$ & 4.33 & 2.22 & $3.92^{\mathrm{b}}$ & 3.54 \\
\hline $\begin{array}{l}\text { Higher education 3-4 } \\
\text { years }\end{array}$ & 90 & 3.48 & $3.75^{\mathrm{a}}$ & 4.15 & $1.86^{\mathrm{b}}$ & 3.64 & 3.38 \\
\hline $\begin{array}{c}\text { Higher education } \\
5+\text { years }\end{array}$ & 42 & 3.40 & $3.49^{\mathrm{a}}$ & 4.22 & $1.79^{\mathrm{b}}$ & $3.87^{\mathrm{b}}$ & 3.73 \\
\hline Personal Income DKK & & $\mathrm{F}=0.851$ & $\mathrm{~F}=4.941^{* *}$ & $\mathrm{~F}=2.018$ & $\mathrm{~F}=1.748$ & $\mathrm{~F}=2.644^{*}$ & $\mathrm{~F}=0.333$ \\
\hline$<100000$ & 38 & 3.43 & $3.85^{\mathrm{b}}$ & 4.19 & 2.40 & $3.29^{\mathrm{a}}$ & 3.53 \\
\hline 100 000-199999 & 33 & 3.30 & $3.21^{\mathrm{a}}$ & 4.01 & 2.06 & 3.41 & 3.29 \\
\hline $200000-299000$ & 47 & 3.53 & $4.07^{\mathrm{b}}$ & 4.47 & 2.01 & $3.81^{\mathrm{b}}$ & 3.40 \\
\hline $300000-399000$ & 70 & 3.49 & $3.91^{\mathrm{b}}$ & 4.44 & 2.03 & $3.78^{\mathrm{b}}$ & 3.46 \\
\hline 400000 or more & 56 & 3.27 & $3.82^{\mathrm{b}}$ & 4.18 & 1.98 & $3.77^{\mathrm{b}}$ & 3.48 \\
\hline
\end{tabular}

Note: 100000 DKK approximates to 16500 USD

* and ** denote significance at the 0.05 and 0.01 levels respectively.

Means with different letters differ significantly based on multiple range tests at the 0.05 level.

Significant differences were found between gender groups for five of the six motivational factors. Female travelers rated 'exploration', 'escape/relaxation', 'social relationship with family/friends' and 'famous sites/heritages' significantly higher their male counterparts. Male travelers, on the other hand, rated 'prestige/impression' significantly higher than female travelers. Age groups were found to vary significantly on three of the six factors. The age groups of 18-24 and 25-34 rated 'prestige/impression' significantly higher than their older counterparts. The age group of 55-64 and 65+ rate 'social relationship with family/friends' significantly lower than the lower age groups. These age groups, on the other hand, rated 'appreciating natural resources' significantly higher than the age groups below 55. Finally, the age groups 45-54 and 55+ rated 'appreciating natural resources' significantly higher than age groups below 45 .

In terms of educational background, the results show significant differences for three of the six motivational factors. Travelers with high school or college being their highest education showed the highest mean score on the 'escape/relaxation' factor. Travelers with primary school being their highest education rate the 'prestige/impression' factor significantly more important than travelers with a higher education of 3 years or more. And finally, travelers with primary school as their highest education rate "natural resources' significantly lower than the high school/college group.

With respect to income groups, the mean scores are significantly different among two of the five motivational factors. Travelers with an income level between 100000 and 199000 DKK (100 000 Danish kroner approximates to 16500 USD) rate 'escape/relaxation' significantly lower than travelers from other income groups. Travelers with an income below 100000 DKK rate 'appreciate natural resources' significantly less than travelers from income groups above 200000 DKK..

\subsection{The Relationship between Travel Motivation and Choice of Vacation}

To check if travel motivations influence travelers' choice of vacation (destination and travel type) a series of t-tests were conducted to examine differences in the motivational factors among different destinations and travel types. The mean scores for each destination along with the results of the univariate tests are shown in Table 3.

As the results show all three destination regions (Denmark, Europe, Outside Europe) show significant differences on at least one of the six motivational factors. Those who have been on vacation in Denmark within the last five years rate 'natural resources' significantly higher than those who have not done domestic travelling. Those who travel in Europe rate 'escape/relaxation' significantly higher than travelers who have not travelled in Europe. Finally, travelers visiting destinations outside Europe tended to rate 'exploration' and 'famous sites/heritages' significantly more important compared to those who have not traveled outside Europe. 
Table 3. T-tests of mean differences of motivational factors by travelers' choice of vacation type

\begin{tabular}{|c|c|c|c|c|c|c|c|}
\hline Vacation type $\mathrm{e}^{\mathrm{a}}$ & $\mathrm{N}$ & Exploration & $\begin{array}{l}\text { Escape/ } \\
\text { relaxation }\end{array}$ & $\begin{array}{c}\text { Social relation-ship } \\
\text { with } \\
\text { family/friends } \\
\end{array}$ & $\begin{array}{l}\text { Prestige/ } \\
\text { impression }\end{array}$ & $\begin{array}{l}\text { Appreciating } \\
\text { natural } \\
\text { resources } \\
\end{array}$ & $\begin{array}{l}\text { Appreciating } \\
\text { famous } \\
\text { sites/heritages }\end{array}$ \\
\hline $\begin{array}{c}\text { Vacation in } \\
\text { Denmark }\end{array}$ & & $\mathrm{t}=0.394$ & $\mathrm{t}=0.203$ & $\mathrm{t}=-0.497$ & $\mathrm{t}=0.678$ & $\mathrm{t}=-2.205^{* *}$ & $\mathrm{t}=-1.595$ \\
\hline No & 105 & 3.45 & 3.81 & 4.22 & 2.12 & 3.49 & 3.32 \\
\hline Yes & 151 & 3.40 & 3.78 & 4.28 & 2.04 & 3.77 & 3.50 \\
\hline $\begin{array}{l}\text { Vacation in } \\
\text { Europe }\end{array}$ & & $\mathrm{t}=-0.251$ & $\mathrm{t}=-2.644^{* * *}$ & $\mathrm{t}=-1.260$ & $\mathrm{t}=-0.001$ & $\mathrm{t}=0.575$ & $\mathrm{t}=0.416$ \\
\hline No & 18 & 3.35 & 3.25 & 3.85 & 2.07 & 3.83 & 3.53 \\
\hline Yes & 238 & 3.42 & 3.83 & 4.29 & 2.07 & 3.64 & 3.42 \\
\hline $\begin{array}{c}\text { Vacation outside } \\
\text { Europe }\end{array}$ & & $\mathrm{t}=-2.476^{* *}$ & $t=-0.713$ & $\mathrm{t}=0.811$ & $\mathrm{t}=-1.752^{*}$ & $\mathrm{t}=-0.519$ & $\mathrm{t}=-2.164^{* *}$ \\
\hline No & 122 & 3.27 & 3.75 & 4.31 & 1.98 & 3.62 & 3.30 \\
\hline Yes & 134 & 3.55 & 3.83 & 4.21 & 2.16 & 3.69 & 3.56 \\
\hline
\end{tabular}

Note: ${ }^{\text {a }}$ Travelers' responses to the questions of whether they have been on a particular type of vacation within a period of five years

$*, * *$ and $* * *$ denote significance at the $0.10,0.05$ and 0.01 levels respectively (two-sided t-tests)

Table 4. T-tests of mean differences of motivational factors by travelers' choice of vacation type

\begin{tabular}{|c|c|c|c|c|c|c|c|}
\hline Vacation type $^{\mathrm{a}}$ & $\mathrm{N}$ & Exploration & $\begin{array}{c}\text { Escape/ } \\
\text { relaxation }\end{array}$ & $\begin{array}{c}\text { Social relation-ship } \\
\text { with } \\
\text { family/friends } \\
\end{array}$ & $\begin{array}{l}\text { Prestige/ } \\
\text { impression }\end{array}$ & $\begin{array}{l}\text { Appreciating } \\
\text { natural } \\
\text { resources } \\
\end{array}$ & $\begin{array}{l}\text { Appreciating } \\
\text { famous } \\
\text { sites/heritages }\end{array}$ \\
\hline Charter & & $\mathrm{t}=0.897$ & $\mathrm{t}=-2.871^{* * *}$ & $t=-0.856$ & $\mathrm{t}=-1.460$ & $\mathrm{t}=2.586^{* * *}$ & $\mathrm{t}=1.195$ \\
\hline No & 103 & 3.48 & 3.60 & 4.20 & 1.98 & 3.85 & 3.52 \\
\hline Yes & 153 & 3.38 & 3.93 & 4.30 & 2.14 & 3.53 & 3.37 \\
\hline Beach vacation & & $\mathrm{t}=-0.418$ & $\mathrm{t}=-2.282^{* *}$ & $\mathrm{t}=-2.679^{* * *}$ & $\mathrm{t}=-1.291$ & $\mathrm{t}=0.854$ & $\mathrm{t}=0.433$ \\
\hline No & 170 & 3.40 & 3.71 & 4.16 & 2.03 & 3.70 & 3.46 \\
\hline Yes & 86 & 3.45 & 3.96 & 4.46 & 2.17 & 3.59 & 3.40 \\
\hline 'Last minute' & & $\mathrm{t}=0.897$ & $\mathrm{t}=-2.151^{* *}$ & $\mathrm{t}=-0.521$ & $\mathrm{t}=0.010$ & $\mathrm{t}=-0.520$ & $\mathrm{t}=0.816$ \\
\hline No & 233 & 3.43 & 3.76 & 4.25 & 2.07 & 3.65 & 3.45 \\
\hline Yes & 23 & 3.26 & 4.18 & 4.33 & 2.07 & 3.76 & 3.28 \\
\hline Round trip & & $\mathrm{t}=-1.718^{*}$ & $\mathrm{t}=-1.079$ & $\mathrm{t}=0.297$ & $\mathrm{t}=0.142$ & $\mathrm{t}=-2.001^{* *}$ & $\mathrm{t}=-2.203^{* *}$ \\
\hline No & 186 & 3.36 & 3.76 & 4.27 & 2.08 & 3.59 & 3.35 \\
\hline Yes & 70 & 3.57 & 3.89 & 4.23 & 2.06 & 3.86 & 3.65 \\
\hline City Break & & $\mathrm{t}=-2.065^{* *}$ & $\mathrm{t}=-0.919$ & $\mathrm{t}=0.617$ & $t=-0.464$ & $\mathrm{t}=0.769$ & $\mathrm{t}=-1.661^{*}$ \\
\hline No & 95 & 3.27 & 3.72 & 4.30 & 2.04 & 3.72 & 3.30 \\
\hline Yes & 161 & 3.51 & 3.83 & 4.23 & 2.09 & 3.62 & 3.50 \\
\hline Driving vacation & & $\mathrm{t}=-0.214$ & $\mathrm{t}=0.867$ & $\mathrm{t}=-0.820$ & $\mathrm{t}=0.553$ & $\mathrm{t}=-2.351^{* *}$ & $\mathrm{t}=-1.879^{*}$ \\
\hline No & 134 & 3.41 & 3.80 & 4.22 & 2.10 & 3.53 & 3.33 \\
\hline Yes & 122 & 3.43 & 3.78 & 4.31 & 2.04 & 3.81 & 3.55 \\
\hline Camping & & $\mathrm{t}=-0.861$ & $t=-0.390$ & $\mathrm{t}=-1.961^{* *}$ & $\mathrm{t}=0.686$ & $\mathrm{t}=-1.389$ & $\mathrm{t}=-0.501$ \\
\hline No & 175 & 3.39 & 3.78 & 4.18 & 2.10 & 3.60 & 3.41 \\
\hline Yes & 81 & 3.49 & 3.83 & 4.43 & 2.02 & 3.78 & 3.48 \\
\hline Skiing & & $\mathrm{t}=1.962^{* *}$ & $\mathrm{t}=-2.439^{* *}$ & $\mathrm{t}=-1.778^{*}$ & $\mathrm{t}=0.492$ & $\mathrm{t}=0.647$ & $\mathrm{t}=2.152^{* *}$ \\
\hline No & 177 & 3.49 & 3.71 & 4.20 & 2.09 & 3.69 & 3.52 \\
\hline Yes & 79 & 3.26 & 3.99 & 4.41 & 2.04 & 3.60 & 2.24 \\
\hline
\end{tabular}

Note: ${ }^{\text {a }}$ Travelers' responses to the questions of whether they have been on a particular type of vacation within a period of five years

$*, * *$ and $* * *$ denote significance at the $0.10,0.05$ and 0.01 levels respectively (two-sided t-tests) 
The results in Table 4 indicate that each of the eight vacation types differ significantly on at least one of the motivational factors, thereby indicating that different travel motivations produce desires for different vacation types. Charter tourists rate 'escape/relaxation' significantly higher and 'natural resources significantly lower compared to non-charter travelers. Beach vacationers rate 'escape/relaxation' and 'social relationship with family/friends' is significantly higher compared to other travelers. Last minute travelers rate 'escape/relaxation' significantly higher compared to those who do not use 'last minute', whereas round trippers rate 'exploration', 'natural resources' and 'famous sites/heritages' significantly higher compared to other travelers. City breakers rate 'exploration' and 'famous sites/heritages' significantly higher compared non-city break travelers. Driving vacation travelers rate 'natural resources' and 'famous sites/heritages' significantly higher compared to other travelers. Campers rate 'social relationship with family/friends' is significantly higher than non-campers. And finally, skiers rate 'escape/relaxation' and 'social relationship with family/friends' significantly higher and 'exploration' and 'famous sites/heritages' significantly lower than non-skiers.

\section{Conclusions and Implications}

This study examined travel motivations of Danish travelers. Using principal component analyses, six motivational factors were extracted: 'exploration', 'escape/relaxation', 'social relationship with family/friends', 'prestige/impression', 'appreciating natural resources' and 'appreciating famous sites/heritages'. The thematic contents of these factors are similar to those identified in previous research on travel motivations (e.g. [5,6] ). All factors other than the 'prestige/impression' motive were rated fairly important by the Danish travelers. In contrast to previous research on travel motivations among travelers from other countries, this study identified 'social relationship with family/friends' as the most important motivational factor for Danish travelers. Such knowledge may be useful for tourism marketers to develop and promote travel products towards Danish travelers. Marketing efforts emphasizing social relationship and family togetherness may be more effective among Danish travelers compared to travelers from other countries.

Yet, at the same time, it is important that tourism marketers do not perceive the Danish travelers as just one homogeneous target group. This study showed that the importance of the six motivational factors varied significantly with travelers' socio-demographic variables and choice of vacation. Females rated four of the six motivational factors ('exploration', 'escape/relaxation', 'social relationship with family/friends' and 'appreciating famous sites/heritages') significantly higher than did their male counterparts, whereas male travelers, especially the younger age groups, rated the 'prestige/impression' factor higher than females. These findings are partly consistent with previous studies which found that females rated relaxation, socializing and exploration as more important than the male respondents (e.g., $[4,6])$. The results also indicate that the travelers aged 55 or above differ from the younger age groups by placing less importance on 'social relationship with family/friends' and more importance on 'natural resources'. It is also notable that travelers with higher income and educational level place more importance on 'natural resources' compared to those who are less educated and have lower income. Also these findings are similar to Kim et al.'s [6] study indicating that travelers aged 50 or above rated family togetherness lower and natural resources higher than their younger counterparts and travelers with higher income levels rated natural resources higher than did the lower income groups. The results clearly suggest that tourism marketers should develop different travel products and promotional programs targeted at travelers with different socio-demographic characteristics. For example, relaxation and family relationship could be highlighted for younger and mid-aged female travelers, whereas travel products emphasizing natural resources may be promoted for older and high-income travelers.

Of special interest in this study was the relationship between travel motivations and choice of vacation. The results showed that travel motives affect the travelers' choice of destination and travel type. For example, those traveling domestically were more concerned with natural resources than those who did not. National tourist organizations and the domestic tourist industry may therefore consider emphasizing the natural resources in Denmark in order to prevent the Danish travelers from traveling abroad. Likewise, those who have been on a vacation outside Europe are more likely to place importance on exploration, famous sites/heritages and prestige. These findings suggest that tourism marketers promoting destinations outside Europe may attract Danish travelers by emphasizing the thrill of and prestige in exploring famous sites and heritages by visiting their home countries.

With regard to travel type, each of the eight travel types included in the study was significantly related to at least one of the six motivational factors. For example, to mention a few relationships, charter tourists placed more importance on 'escape/relaxation' and less importance on 'prestige/impression' compared to those who have not traveled by charter. Beach vacationers emphasize 'escape/relaxation' and 'social relationship with family/friends' higher than those who have not been on a beach vacation. Round trip and city break travelers placed more importance on the 'exploration' factor and appreciated famous sites and heritages more than those who have not been on round trip or city break vacations. And finally, skiing tourists, in contrast to round trip and city break vacationers, rated these motivational factors relatively low and placed more importance on escape/relaxation and family/social relationship compared to non-skiing vacationers. Tourist marketers can capitalize on knowledge of such relationships. For example, marketers promoting 
skiing resorts may attract Danish skiing tourists by emphasizing the relaxation aspects and social aspects experienced when staying at their resort.

\section{Limitations and Suggestions for Further Research}

As with any study of this nature, there are some limitations that could be addressed in future studies. First, the generalizability of the results may be limited because only households with access to the Internet were recruited for the study. Also the sample size of 256 respondents is relatively small. Yet, it should be noted that, according to Eurostat [18], household Internet penetration in Denmark is relatively high (around 95\%). Future research on the relationships between travel motivations and the travelers' choice of vacation may use larger sample sizes and recruiting also households without access to the Internet. Second, the list of travel motivations captured in this study may not be exhaustive. Future studies may expand the list of travel motivations to include other motivational aspects. Third, only Danish travelers were recruited for this study. Although several findings in this study parallel evidence from previous research conducted in other countries, it also showed that travel motivations differ across nationalities. It would therefore be of value to conduct similar studies with travelers from other countries. Fourth, in this study the travelers' choice of vacation were measured by asking respondents to indicate whether or not they have been on a particular vacation type within a period of five years. Although, the results indicated that the importance of motivational factors differ significantly between those who have been on a particular type of vacation and those who have not, the detected relationships do not prove whether a specific motivational factor actually was pushing the travelers towards a particular vacation type. Future studies may measure the motivational factors in a more context-related way, for example, by asking travelers about the importance of the travel motives with regard to a specific type of vacation.

\section{REFERENCES}

[1] Fodness, D., Measuring tourist motivation, Annals of Tourism Research, Vol. 21 No.3, pp. 555-581, 1994.

[2] Crompton, J. L., Motivations for Pleasure Vacation, Annals of Tourism Research, Vol. 6 No.4, pp. 408-424, 1979.

[3] Dann, G. M. S., Tourist Motivation: An Appraisal, Annals of
Tourism Research, Vol. 8 No.2, pp. 187-219, 1981.

[4] Gitelson, R. J. and Kerstetter, D. L., The Relationship Between Sociodemographic Variables, Benefits Sought and Subsequent Vacation Behavior, Journal of Travel Research, Vol. 28 No.3, pp. 24-29, 1990.

[5] Kau, A. K. and Lim, P.S., Clustering of Chinese Tourists to Singapore: An Analysis of Their Motivations, Values and Satisfaction, International Journal of Tourism Research, Vol. 7 No.4-5, pp. 231-248, 2005

[6] Kim, S.S., Lee, C. K. and Klenosky, D.B., The influence of push and pull factors at Korean national parks, Tourism Management, Vol. 24 No. 2, pp. 169-180, 2003

[7] Kozak, M., Comparative analysis of tourist motivations by nationality, Tourism Management, Vol. 23 No. 3, pp. 221-232, 2002

[8] Park, D. B and Yoon, Y.S., Segmentation by motivation in rural tourism: A Korean case study. Tourism Management, Vol. 30 No. 1, pp. 99-108, 2009

[9] Heung, V., Qu, H. and Chu, R., The relationship between vacation factors and socio-demographic and travelling characteristics: the case of Japanese leisure travelers, Tourism Management, Vol. 22 No.3, pp.259-269, 2001.

[10] Botha C., Crompton, J. L. and Kim, S.S., Developing a revised competitive position for Sun/Lost city, South Africa, Journal of Travel Research, Vol. 37 No. 4, pp. 341-352, 1999.

[11] Cha, S., McCleary, K. and Uysal, M., Travel motivation of Japanese overseas travelers. A factor-cluster approach, Journal of Travel Research, Vol. 33 No. 3, pp. 33-39, 1995.

[12] Jang, S. C. S. and Wu, C. M. E., Seniors' travel motivation and the influential factors: An examination of Taiwanese seniors, Tourism Management, Vol. 27 No. 2, pp. 306-316, 2006.

[13] Pearce, P. and Lee, U. L., Developing the travel career approach to tourist motivation, Journal of Travel Research, Vol. 43 No. 3, pp. 226-237, 2005.

[14] Zimmer, Z., Brayley, R. and Searle, M., Whether to go and where to go: Identification of important influences on seniors' decision to travel, Journal of Travel Research, Vol. 33 No.3, pp. 3-8, 1995

[15] Sangpikul, A., Travel motivations of Japanese Senior Travellers to Thailand, International Journal of Tourism Research, Vol. 10 No. 1, pp. 81-94, 2008

[16] Bansal, H. and Eiselt, H. A., Explorative research of tourist motivations and planning, Tourism Management, Vol. 25 No.3, pp. 387-396, 2004

[17] Hair Jr., J. F., Black, W. C., Babin, B. J. and Anderson, R. E., Multivariate Data Analysis: A Global Perspective, London: Pearson, 2010.

[18] http://ec.europa.eu/eurostat/statistics-explained/index.php/Inf ormation society statistics - households and individuals 